\section{Skin color, social inequalities and health in older adults: an analysis based on the SABE survey in Colombia}

\author{
Cor da pele, desigualdades sociais e saúde em \\ idosos: uma análise a partir do inquérito \\ SABE na Colômbia
}

Color de piel, inequidades sociales y salud en adultos de edad avanzada: un análisis basado en la encuesta SABE en Colombia

\begin{abstract}
Our study is based on the Colombia SABE survey (Health, Well-Being, and Aging Study), which included 23,694 individuals aged 60+ in urban and rural areas of the country. The analysis addresses adult self-perception of health status as a dependent variable and its relationships to ethnic/racial self-recognition and to interviewer-ascribed skin color as a phenotypic trait using a validated technique with a color palette. Social inequalities were determined based on the characterization of socioeconomic status, urban or rural residence, literacy, and the average years of education attained. Our study brought together socioeconomic factors, ethnic-racial self-recognition and skin color as factors of discrimination. Descriptive statistical tests and four adjusted logistic models were developed, controlling by the sex and the age of the individuals. The findings show that adults in households with better socioeconomic conditions have a better self-perception of health. Regarding ethnic-racial self-recognition, Afro-descendant, black, and mulatto adults have less good health perception than white-mestizo adults and face the worst socioeconomic conditions. In summary, skin color and ethnic and racial selfrecognition categories, together with classic socioeconomic variables, are relevant to understand the health status self-perception of older adults as part of the processes of exclusion and discrimination that have consequences for health inequalities.
\end{abstract}

Ethnic Groups; Racism; Social Inequity; Adult Health
Fabian Mendez 1

Fernando Urrea-Giraldo 1

Delia Ortega 1

doi: 10.1590/0102-311X00121419

\author{
Correspondence \\ F. Mendez \\ Condominio La Riverita, casa 8, Cali 760031, Colombia. \\ fabian.mendez@correounivalle.edu.co \\ 1 Universidad del Valle, Cali, Colombia.
}




\section{Introduction}

According to Lasso 1 and Urrea et al. 2, Spanish colonial practices were based on categorizing individuals into castes. Based on a classification of mixtures among white Spanish, indigenous, and black populations, the colonial system created a combination model (i.e.; white-indigenous, black-white, black-indigenous) supported arbitrarily by the physical and cultural traits perceived at that time, as described and analyzed in Mexico by Vinson III 3. This caste regime preceded the emergence of the notion of race in Colombia, which appeared in the nineteenth century 4 , leaving the historical basis of a legacy of racism and long-term discrimination in Colombian society 5,6. Colombia became independent from Spain and three decades later, in 1851, slavery was abolished in the country; however, the elimination of the colonial caste regime did not mean the disappearance of ethnic-racial discrimination. In contrast, differences have prevailed in Latin American societies with Hispanic, Portuguese and other colonial pasts. In particular, ethnic-racial discrimination manifests itself in different forms of social exclusion not related to social class and socioeconomic status through forms of spatial segregation and political, educational, occupational, and cultural barriers ${ }^{7}$. Subsequently, the historical discrimination and segregation processes that include ethnic-racial variables, which are also of social status, and gender create the basis for the configuration of social inequalities in health, as has been described by the model of the World Health Organization Commission on Social Determinants of Health 8 .

According to the Economic Commission for Latin America and the Caribbean 9, Latin America, and especially Colombia, present the highest levels of inequality measured by the household Gini coefficient, the income of the wealthiest social classes, and other indicators used to measure inequality. Recent studies on social inequality in Latin America, which integrate economic inequality with other dimensions, point to the importance of the ethnic-racial component in this inequality. However, this ethnic-racial aspect has been suggested to be better visualized in the phenotype through skin color and hair type 10,11,12, as demonstrated through the application in various sample surveys of the "color palette" instrument that enables the interviewer to perform an external heteroclassification. This application contrasts with the measurement of inequality through the ethnic-racial variable of self-recognition based on the subjectivity of the individual and involves processes of identification and personal valuation of an ethnic-political nature. The methodological strategy of heteroclassification, as developed in a study by Telles et al. 10 through the Project on Ethnicity and Race in Latin America (PERLA), reveals that social inequality is more visible and better measured through the color palette than through ethnic-racial self-recognition categories. Other studies have reached similar conclusions based on the Latin American Public Opinion Project (LAPOP) or AmericasBarometer of Vanderbilt University Survey, which have used the color palette in national samples from 24 countries in Latin America since 2010. According to these last studies, there is a "pigmentocratic" effect on social inequality in the entire region for various Latin American countries different from the PERLA samples of four countries (Brazil, Colombia, Mexico and Peru) 13,14,15.

The main objective of our study was to analyze, among population over 60 years of age, the relationship of ethnic-racial variables to self-perception of the health status, an indicator that has demonstrated its association with mortality, the health of the population, and the demand for health care. In particular, at the individual level, self-rated health has been shown to predict mortality in older adults 16 . A central antecedent to our study is that performed by Perreira \& Telles 17 with the specific evaluation of the pigmentocratic effect on the subjective perception of health for all ages in the four countries in the PERLA sample, Colombia included. Our study focused attention in older people.

Population aging in Colombia is characterized by an advanced demographic transition with a reduction in the fertility rate, an increase in the proportion of working age individuals, a reduction in the child population, and an increase in the population over 60 years of age 18 . Throughout their lifetimes, these older adults incorporated in their bodies - "embodied" in terms of Nancy Krieger 19 - the social inequalities, including those of ethnic-racial status; therefore, they become particularly vulnerable populations.

Based on data from the Health, Well-Being, and Aging (SABE) survey in Colombia, this article seeks to contribute to the understanding of the role of social and health inequalities associated with the ethnic-racial variable using self-rated health as a result variable. Moreover, we evaluated the relation- 
ship of the ethnic-racial component in its dimensions of skin color and ethno-racial self-recognition with variables of socioeconomic stratum, such as residence in urban or rural area, socioeconomic conditions in the household, educational level, literacy, and social security type of the older adult. In the analysis, special consideration also came from the perception of the older adult having been subject to discrimination due to factors related to ethnic-racial or socioeconomic status.

\section{Methods}

The 2015 Colombia SABE survey is a cross-sectional study on the living and health conditions of people over 60 years of age in urban and rural areas of the country. The protocol and sample design of the survey are detailed in the publication by Gómez et al. ${ }^{20}$, and some of the most important methodological aspects are as follows.

The survey included a questionnaire for the population of older adults with information related to socioeconomic aspects, physical and social environments, behavior, cognition and affection, functionality, mental well-being, and medical and health conditions, including self-rated health and access to health services; taking physical measurements; functionality tests in a subsample; arterial pressure readings; and determination of glucose levels, lipid profile, and hemoglobin.

The final sample size was 23,694 older adults of 246 municipalities throughout the national territory, with representativeness at the level of 5 regions of Colombia and self-representativity for large cities, including Bogotá. The probabilistic sampling of the households was by cluster and multistage and was stratified between urban and rural areas.

To evaluate the social determinants of health, SABE included the characterization of socioeconomic conditions of older adults using the following variables: socioeconomic stratum (SES categorized as: 1, the poorest; 2, 3-4 and 5-6, the wealthiest); urban/rural area; ability to read/write; number of years of education; and social security affiliation (contributory/subsidized/for exception or special/non-affiliated). Additionally, a composite indicator of socioeconomic status was constructed and adapted to the SABE variables from the multidimensional poverty index developed by the World Bank 21. Based on the housing conditions of the household, the following were evaluated: (i) water sources; (ii) excreta disposal; (iii) cooking tools; (iv) household assets (list); (v) floor materials; (vi) roof materials; (vii) wall materials; and (viii) critical overcrowding (three or more people per room available other than the living and dining rooms). To estimate the value of this composite indicator between 0 and 1 (with values close to 1 representing larger gaps in household conditions), a multiple correspondence analysis (MCA) was developed, in which the variables were dichotomously categorized. Since a single form was created per household, the indicator analysis unit coincides with the unit of observation (older adult and household, respectively). The indicator was analyzed quantitatively by considering the scores obtained through the MCA, although for some analyses the values were ordered by quintiles from least to most deprivation. In one of the tests, quintiles 1,2, and 3 were grouped - those with less deprivation - versus quintiles 4 and 5 -those with the most deprivation.

The ethnic-racial variable, as another social determinant of health, was included in the SABE through a module of ethnic-racial self-recognition with two questions based on the respondent's subjectivity (i.e., according to self-recognition). The first question was of an ethnic type using the same question from the 2005 Colombian Population and Housing Census of the National Statistics Department (DANE). The interviewer asked: "According to your culture, people or physical traits do you recognize yourself as...?", and read and selected only one of a list that included: "indigenous", "gypsy", "raizal", "palenquero", "black/afrodescendant/afrocolombian" or "none of the above". The second question was racial in nature using the LAPOP survey question: "You consider yourself a person..." and the interviewer read and selected only one of the following list: "indigenous", "black", "mulatto", "white", "mestizo", or "other". We also included the criterion of external heteroclassification through the interviewer by using a color palette with 11 skin colors and that has been widely validated and used in Latin America via PERLA 10 and LAPOP 22 surveys (Figure 1). Specifically, the interviewer classifies the face of the person interviewed into one of the 11 colors of the palette, with 1 being the lightest color and 11 being the darkest color. For the analysis of this variable, the population was categorized 


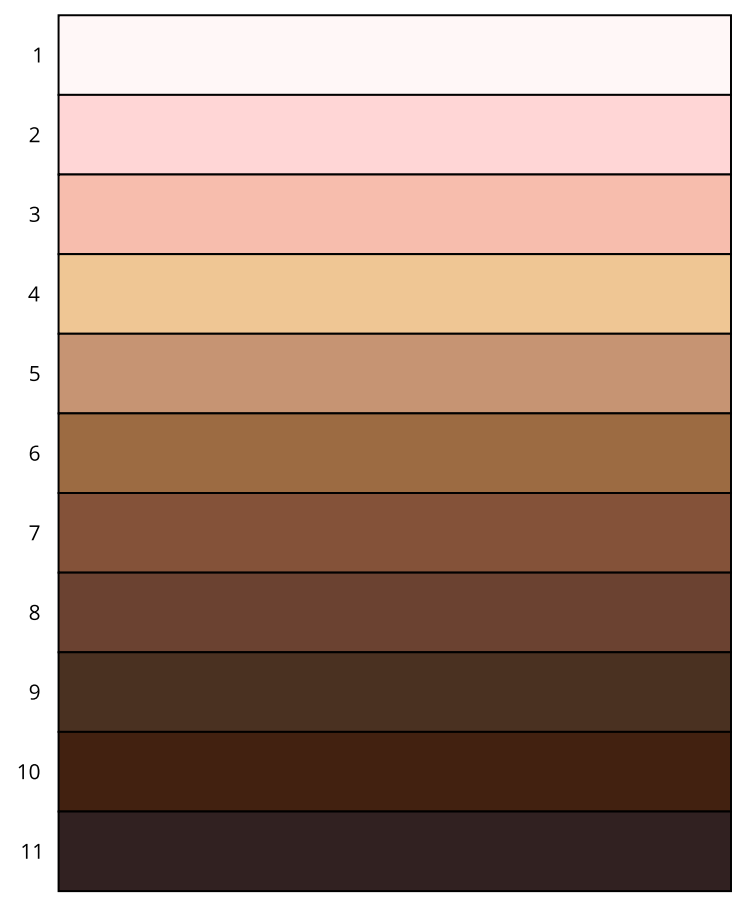

Note: question at SABE survey, Colombia, 2015. Interviewer: "This item is done by observation, it is not a question, but consists of assigning a number of the color scale, from 1 to 11 , to the skin color of the face of the person interviewed. What is the skin color of the face of this person?".

into three groups: (i) light skin colors (1-3 on the color palette scale), (ii) intermediate (4 and 5), and (iii) dark skin (6-11).

In contrast, class and ethnic-racial discrimination were also analyzed throughout their lives using the following questions: "Have you felt rejected or discriminated due to socioeconomic stratum?" or "Have you felt rejected or discriminated because of your ethnicity/race?". For both questions, the response options were dichotomous (yes/no).

The outcome variable of primary interest was the self-perceived health of the older adult, which characterizes whether his/her health has been very bad, bad, fair, good, or very good in the prior 30 days in the opinion of the interviewee. For logistic regression models, and following the common practice with this variable, the categories were dichotomized combining the top two categories (very good/good) and the bottom three categories (fair/bad/very bad). The initial analyses were developed to characterize social inequalities according to the two criteria used in the ethnic-racial self-awareness survey and the external validation criterion using the color palette. Next, descriptive graphs, linear and logistic regression analysis were used to describe the association between skin color based on the color palette and the different socioeconomic and discrimination variables.

Finally, multiple logistic regression models adjusted for age and gender were constructed to evaluate the association of the ethnic-racial variables with self-rated health. These associations were additionally adjusted for the SES condition variables in different multiple regression models. All regression models were estimated with $95 \%$ confidence intervals (95\% CI) and considering the expansion factors of the multistage sampling of the SABE survey. 
Most analyses were based on socio-demographic variables with low proportion of missing observations, predominantly around $1 \%$, and therefore no imputation or other methods for dealing with missing data were implemented.

\section{Results}

According to the three established color palette categories, $48.4 \%$ of the older adult population was classified as having clear skin, $36.7 \%$ as having medium-colored skin, and the remaining $14.9 \%$ of people as having dark skin. The values of the skin color distribution showed consistency with both the ethnic-racial characterization variable and racial self-recognition. Specifically, older adults with skin color in the highest values of the color palette are generally recognized as Afro-descendant, black, or mulatto (Figure 2).

Among the total older adult population in the Colombia SABE, 52,5\% were between 60 and 69 years of age, one-third were between 70 and 79 years of age (30.2\%), and the rest were older than 80 years of age (12.9\%). Additionally, among all older adults, the higher proportion of women (54.5\%) increases with age (from $52.9 \%$ between $60-69$ years to $58.8 \%$ from 80 and older years).

Differences were observed in the distribution of skin color categories between urban and rural areas. In particular, among people with darker skin color, more than one-third (35\%) live in rural areas, and this proportion of the rural population is lower for those with medium-colored skin (27.7\%) and those with clear skin (15.5\%) (Table 1).

In contrast, the distribution by sex (man-woman) in the sample when performing the same control by color palette indicates an inverse relationship between the sex ratio (ratio of men to women) according to the three large skin color groups. Older adults with lighter skin have the lowest sex ratio (0.69 men per woman), those with intermediate skin are close to one (0.99 men per woman), and those with dark skin have the highest value (1.18 men per woman).

The majority of the adults with dark skin color belonged to socioeconomic strata 1 and 2 (i.e., $51.9 \%$ in SES 1 and $34.3 \%$ in SES 2, a total of 86.2\%) when compared with those with medium (76\%) and light (59.4\%) skin color. This disparity is partially because dark-skinned people mostly live in rural areas and due to their lowest participation in the educational and occupational systems. Within

Figure 2

Skin color averages by color palette according to categories of ethnic self-recognition (2005 Colombian Population and Housing Census of the National Statistics Department - DANE) and racial self-recognition (Latin American Public Opinion Project - LAPOP).

2a) Ethnic self-recognition (DANE question)

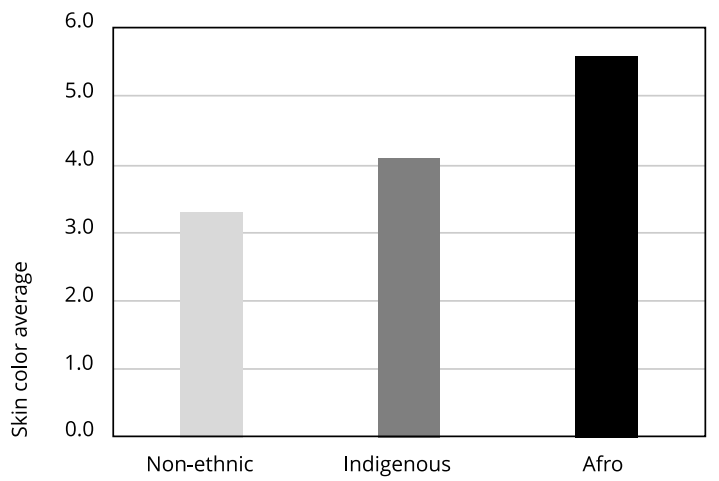

2b) Racial self-awareness (LAPOP question)

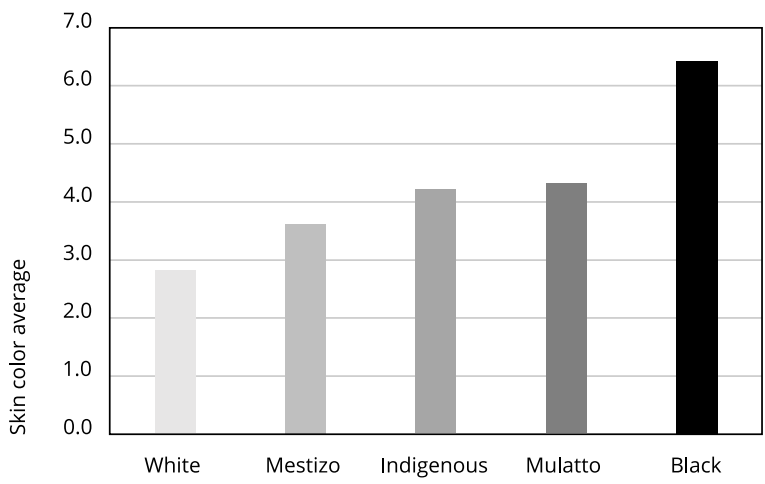


Table 1

Sociodemographic characteristics according to three categorical skin color groups. SABE survey, Colombia, 2015.

\begin{tabular}{|c|c|c|c|c|c|c|c|c|c|}
\hline \multirow[t]{2}{*}{ Characteristics } & \multirow[t]{2}{*}{$\mathrm{n}$} & \multicolumn{2}{|c|}{$\begin{array}{c}\text { Light } \\
(n=11,465)\end{array}$} & \multicolumn{2}{|c|}{$\begin{array}{l}\text { Medium } \\
(n=8,706)\end{array}$} & \multicolumn{2}{|c|}{$\begin{array}{c}\text { Dark } \\
(n=3,523)\end{array}$} & \multicolumn{2}{|c|}{ Total } \\
\hline & & $\%$ & $95 \% \mathrm{Cl}$ & $\%$ & $95 \% \mathrm{Cl}$ & $\%$ & $95 \% \mathrm{Cl}$ & $\%$ & $95 \% \mathrm{Cl}$ \\
\hline \multicolumn{10}{|l|}{ Gender } \\
\hline Men & 10,112 & 41.0 & $39.1 ; 42.8$ & 49.8 & $46.1 ; 53.4$ & 54.2 & $50.2 ; 58.2$ & 45.5 & $44.2 ; 46.7$ \\
\hline Women & 13,582 & 59.0 & $57.2 ; 60.9$ & 50.2 & $46.6 ; 53.9$ & 45.8 & $41.8 ; 49.8$ & 54.5 & $53.3 ; 55.8$ \\
\hline \multicolumn{10}{|l|}{ Age (years) } \\
\hline $60-69$ & 12,101 & 56.0 & $54.1 ; 57.9$ & 58.5 & $56.9 ; 60.1$ & 56.3 & $52.4 ; 60.1$ & 56.9 & $55.5 ; 58.3$ \\
\hline $70-79$ & 7,720 & 30.5 & $28.7 ; 32.4$ & 29.4 & $27.8 ; 31.1$ & 31.0 & $26.9 ; 35.4$ & 30.2 & $29.1 ; 31.4$ \\
\hline 80 and older & 3,873 & 13.5 & $12.3 ; 14.8$ & 12.1 & $10.9 ; 13.4$ & 12.8 & $11.2 ; 14.5$ & 12.9 & $12.2 ; 13.7$ \\
\hline \multicolumn{10}{|l|}{ SES } \\
\hline 1 & 10,313 & 20.8 & $13.7 ; 30.3$ & 33.0 & $23.7 ; 43.8$ & 51.9 & $42.5 ; 61.2$ & 28.4 & $19.5 ; 39.3$ \\
\hline 2 & 9,033 & 38.6 & $36.2 ; 41.1$ & 43.0 & $37.4 ; 48.7$ & 34.3 & $28.3 ; 40.9$ & 39.7 & $36.5 ; 42.9$ \\
\hline $3-4$ & 4,181 & 37.7 & $28.8 ; 47.4$ & 22.8 & $17.4 ; 29.3$ & 13.6 & $8.7 ; 20.5$ & 29.9 & $22.0 ; 39.3$ \\
\hline $5-6$ & 167 & 2.9 & $1.6 ; 5.1$ & 1.2 & $0.6 ; 2.4$ & 0.2 & $0.1 ; 0.6$ & 2.0 & $1.3 ; 3.2$ \\
\hline \multicolumn{10}{|l|}{ Area } \\
\hline Urban & 17,189 & 84.5 & $70.0 ; 92.7$ & 72.3 & $55.7 ; 84.4$ & 65.0 & $47.2 ; 79.5$ & 78.1 & $63.2 ; 88.1$ \\
\hline Rural & 6,505 & 15.5 & $7.3 ; 30.0$ & 27.7 & $15.6 ; 44.3$ & 35.0 & $20.5 ; 52.8$ & 21.9 & $11.9 ; 36.8$ \\
\hline \multicolumn{10}{|c|}{ Socioeconomic condition indicator } \\
\hline Quintile 1 & 4,739 & 25.0 & $16.9 ; 35.2$ & 19.2 & $14.9 ; 24.3$ & 17.1 & $12.8 ; 22.5$ & 22.1 & $15.8 ; 30.0$ \\
\hline Quintile 2 & 4,741 & 22.8 & $18.6 ; 27.6$ & 23.0 & $18.6 ; 28.1$ & 17.7 & $13.4 ; 22.9$ & 22.3 & $18.2 ; 27.0$ \\
\hline Quintile 3 & 4,737 & 20.5 & $15.1 ; 27.2$ & 18.6 & $15.4 ; 22.4$ & 21.2 & $17.3 ; 25.6$ & 19.9 & $15.9 ; 24.7$ \\
\hline Quintile 4 & 4,739 & 14.5 & $10.6 ; 19.4$ & 19.1 & $14.2 ; 25.2$ & 22.5 & $17.7 ; 28.2$ & 17.0 & $12.7 ; 22.3$ \\
\hline Quintile 5 & 4,738 & 17.3 & $12.9 ; 22.8$ & 20.1 & $15.9 ; 25.1$ & 21.5 & $17.2 ; 26.6$ & 18.7 & $14.5 ; 23.9$ \\
\hline \multicolumn{10}{|l|}{ Social security } \\
\hline Contributing & 8,627 & 56.0 & $48.8 ; 62.9$ & 43.4 & $36.3 ; 50.7$ & 30.8 & $23.3 ; 39.6$ & 48.9 & $41.0 ; 56.8$ \\
\hline Subsidized & 14,160 & 39.5 & $32.2 ; 47.3$ & 52.9 & $45.7 ; 59.9$ & 64.9 & $56.8 ; 72.3$ & 46.9 & $38.9 ; 55.1$ \\
\hline Other & 371 & 2.6 & $1.6 ; 4.2$ & 1.2 & $0.7 ; 1.9$ & 1.4 & $0.7 ; 2.8$ & 2.0 & $1.2 ; 3.2$ \\
\hline Unaffiliated & 512 & 1.9 & $1.3 ; 2.7$ & 2.5 & $1.5 ; 3.9$ & 2.7 & $1.9 ; 4.1$ & 2.2 & $1.6 ; 3.0$ \\
\hline \multicolumn{10}{|c|}{ Can read and write } \\
\hline Yes & 18,650 & 90.6 & $87.7 ; 92.9$ & 80.0 & $75.6 ; 83.7$ & 69.1 & $62.5 ; 75.1$ & 84.6 & $80.1 ; 88.2$ \\
\hline No & 5,014 & 9.4 & $7.1 ; 12.3$ & 20.0 & $16.3 ; 24.4$ & 30.9 & $24.9 ; 37.5$ & 15.4 & $11.8 ; 19.9$ \\
\hline \multicolumn{10}{|l|}{ Self-rated health } \\
\hline Very good & 864 & 6.1 & $4.5 ; 8.3$ & 5.1 & $3.8 ; 6.9$ & 3.8 & $2.4 ; 5.8$ & 5.6 & $4.3 ; 7.1$ \\
\hline Good & 8,255 & 46.0 & $42.7 ; 49.4$ & 45.5 & $43.5 ; 47.5$ & 44.7 & $41.1 ; 48.4$ & 45.7 & $43.7 ; 47.8$ \\
\hline Fair & 8265 & 40.9 & $39.0 ; 42.8$ & 41.0 & $39.3 ; 42.7$ & 45.2 & $41.2 ; 49.1$ & 41.4 & $40.3 ; 42.4$ \\
\hline $\mathrm{Bad}$ & 1,448 & 6.2 & $4.5 ; 8.5$ & 7.7 & $5.8 ; 10.2$ & 5.9 & $4.5 ; 7.9$ & 6.7 & $5.2 ; 8.5$ \\
\hline Very bad & 167 & 0.7 & $0.5 ; 0.9$ & 0.6 & $0.4 ; 1.0$ & 0.5 & $0.3 ; 0.8$ & 0.7 & $0.5 ; 0.8$ \\
\hline
\end{tabular}

95\%Cl: 95\% confidence interval; SES: socioeconomic stratum.

the urban area, darker-skinned people have usually residence at more disadvantaged or vulnerable locations, with lower income by household.

The composite indicator of socioeconomic status, which has higher values for individuals with worse home conditions, indicated a trend toward a higher proportion of dark-skinned adults in the upper quintiles (quintiles 4 and 5: 44\%) when compared with adults of medium- and light-colored skin (quintiles 4 and 5: $39.2 \%$ and $31.8 \%$, respectively). The opposite is observable by skin color categories in the lower quintiles, which reflect people with the least deprivations (Table 1). A logistic regression analysis also showed that the odds for the dark-skinned population to belong to quintiles 
4 and 5 is $69 \%$ higher than for light-skinned individuals at a 95\%CI: 1.24; 2.29, regardless of age and gender (Figure 3).

In all groups, the proportion of the population not affiliated with social security is low (2.2\%). However, there are differences in skin color in the distribution of people according to the type of affiliation regime. Among dark-skinned people, nearly two-thirds of the participants (64.9\%) were affiliated with the subsidized scheme offered to the poor population without payment capacity, whereas only $39.5 \%$ of light-skinned people were affiliated with that regime.

Older adults have a low educational level. That is, the estimated average number of years studied was only 4.8 years, and more than half of the people had primary education as their highest level of education (52.5\% of the population). Stratifying by skin color, the average number of school years is even lower for dark-skinned people (only 3.3 years), and is significantly lower than that for the light-

\section{Figure 3}

Differences in skin color in average years of education, socioeconomic conditions, percentage of discrimination by ethnic-racial factor, and socioeconomic stratum (SES).

3a) Average number of years of education

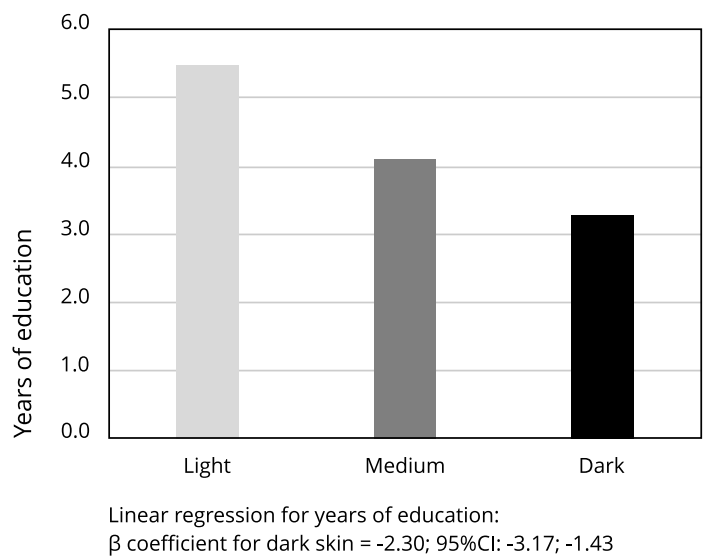

3c) \% discriminated by ethnic-racial factor

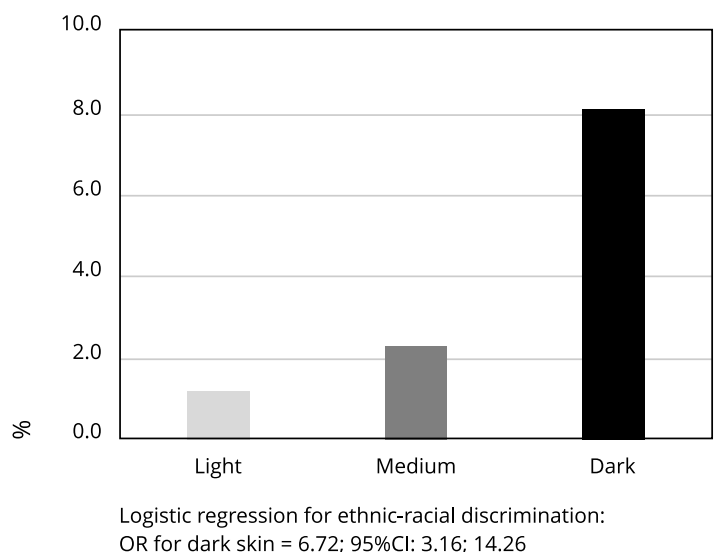

3b) Socioeconomic condition indicator

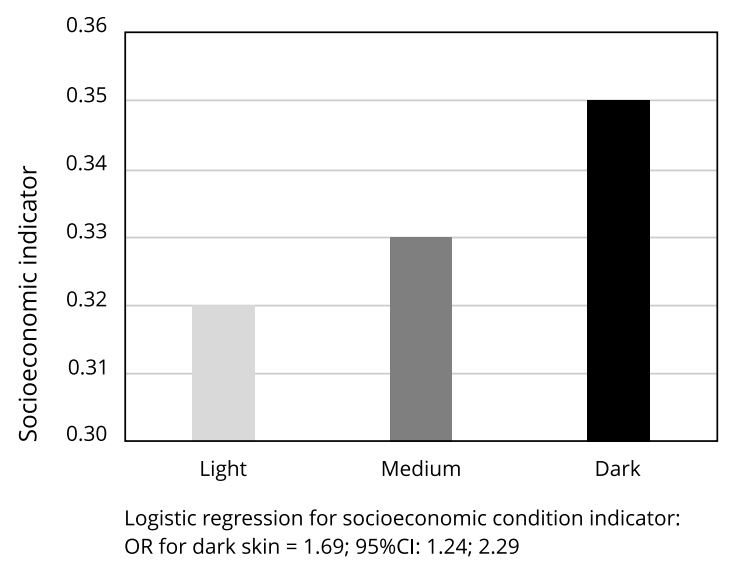

3d) \% discrimitade by SES

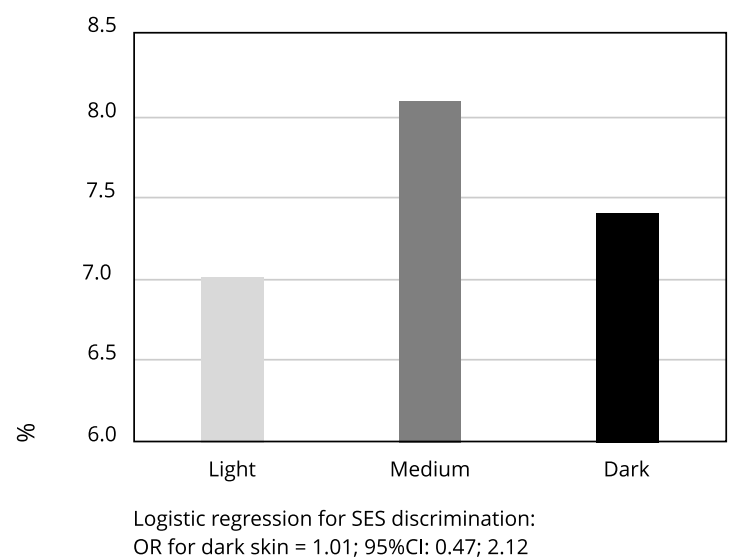


skinned population (linear regression coefficient: -2.3 years; 95\%CI: -3.2; -1.4), regardless of age and gender (Figure 3). Moreover, inability to read and write is three times more frequent in dark-skinned than in light-skinned people (30.9\% vs. $9.4 \%$, respectively).

The perception of discrimination or rejection by the ethnic-racial factor was more frequent in the dark-skinned than in the light-skinned population (8.1\% versus $1.2 \%)$. Likewise, the odds to feel rejected or discriminated in dark-skinned people was 6.72 times the odds of the population with fair skin, adjusted for age and gender (95\%CI: 3.2; 14.3)

Table 2 provides the analysis of the association with self-perceived health in older adults according to ethnic-racial and socioeconomic variables, adjusted for age and gender. All logistic regressions used good/very good health as the outcome of interest compared to bad and the first column shows the univariate estimates of each exposure variable. The estimates suggest a $20 \%$ lower odds $(\mathrm{OR}=$ 0.80; 95\%CI: 0.62; 1.02) for good/very good self-rated health in people with darker skin when compared with those with clear skin. Similarly, the population that racially self-identifies as black has almost a $40 \%$ lower chance of self-perceived good health than the white population (95\%CI: 0.44; 0.84). Likewise, in the ethnically self-identified as Afro population, the odds were $28 \%$ lower than

Table 2

Association with self-perception of health in older adults by ethno-racial and socioeconomic variables *. SABE survey, Colombia, 2015.

\begin{tabular}{|c|c|c|c|c|c|c|c|c|c|c|}
\hline \multirow[t]{2}{*}{ Variables } & \multicolumn{2}{|c|}{ Univariate models } & \multicolumn{2}{|c|}{ Model 1} & \multicolumn{2}{|c|}{ Model 2} & \multicolumn{2}{|c|}{ Model 3} & \multicolumn{2}{|c|}{ Model 4} \\
\hline & OR & $95 \% \mathrm{Cl}$ & OR & $95 \% \mathrm{Cl}$ & OR & $95 \% \mathrm{Cl}$ & OR & $95 \% \mathrm{Cl}$ & OR & $95 \% \mathrm{Cl}$ \\
\hline \multicolumn{11}{|l|}{ Skin color } \\
\hline Light & 1.00 & & 1.00 & & 1.00 & & 1.00 & & 1.00 & \\
\hline Medium & 0.89 & $0.78 ; 1.02$ & 0.93 & $0.80 ; 1.07$ & 0.91 & $0.79 ; 1.05$ & 0.88 & $0.77 ; 1.01$ & 0.94 & $0.82 ; 1.08$ \\
\hline Dark & 0.80 & $0.62 ; 1.02$ & 0.98 & $0.70 ; 1.38$ & 0.89 & $0.66 ; 1.18$ & 0.78 & $0.61 ; 1.00$ & 0.88 & $0.69 ; 1.14$ \\
\hline \multicolumn{11}{|l|}{ Racial self-awareness (LAPOP question) } \\
\hline White & 1.00 & & 1.00 & & & & & & & \\
\hline Black & 0.61 & $0.44 ; 0.84$ & 0.62 & $0.40 ; 0.94$ & & & & & & \\
\hline Mulatto & 0.65 & $0.42 ; 1.01$ & 0.67 & $0.44 ; 1.04$ & & & & & & \\
\hline Indigenous & 0.89 & $0.75 ; 1.06$ & 0.91 & $0.76 ; 1.08$ & & & & & & \\
\hline Mestizo & 1.02 & $0.86 ; 1.21$ & 1.04 & $0.87 ; 1.23$ & & & & & & \\
\hline Other & 0.89 & $0.66 ; 1.20$ & 0.91 & $0.68 ; 1.21$ & & & & & & \\
\hline Don't know/No respond & 0.82 & $0.67 ; 1.00$ & 0.83 & $0.67 ; 1.04$ & & & & & & \\
\hline \multicolumn{11}{|l|}{ Ethnic self-awareness } \\
\hline Non-ethnic & 1.00 & & & & 1.00 & & & & & \\
\hline Afro & 0.72 & $0.60 ; 0.87$ & & & 0.76 & $0.61 ; 0.95$ & & & & \\
\hline Indigenous & 0.95 & $0.77 ; 1.16$ & & & 0.96 & $0.78 ; 1.19$ & & & & \\
\hline Other groups (rom, palenquero, raizal) & 1.70 & $1.18 ; 2.45$ & & & 1.74 & $1.22 ; 2.47$ & & & & \\
\hline \multicolumn{11}{|l|}{ Socioeconomic condition } \\
\hline Quintile 1 & 1.00 & & & & & & 1.00 & & & \\
\hline Quintile 2 & 1.13 & $0.84 ; 1.53$ & & & & & 1.14 & $0.85 ; 1.53$ & & \\
\hline Quintile 3 & 1.08 & $0.75 ; 1.55$ & & & & & 1.09 & $0.78 ; 1.54$ & & \\
\hline Quintile 4 & 1.17 & $0.89 ; 1.53$ & & & & & 1.20 & $0.94 ; 1.54$ & & \\
\hline Quintile 5 & 1.06 & $0.76 ; 1.47$ & & & & & 1.08 & $0.79 ; 1.46$ & & \\
\hline Ethnic/Racial discrimination & 0.45 & $0.26 ; 0.77$ & & & & & & & 0.61 & $0.34 ; 1.08$ \\
\hline SES discrimination & 0.56 & $0.43 ; 0.74$ & & & & & & & 0.60 & $0.46 ; 0.77$ \\
\hline Unable to read and write & 0.74 & $0.60 ; 0.90$ & & & & & & & 0.83 & $0.67 ; 1.03$ \\
\hline Live in rural area & 0.71 & $0.58 ; 0.87$ & & & & & & & 0.73 & $0.60 ; 0.91$ \\
\hline
\end{tabular}

95\%Cl: 95\% confidence interval; LAPOP: Latin American Public Opinion Project; OR: odds ratio; SES: socioeconomic stratum.

*All logistic regressions estimate ORs on good/very good health as compared to fair/bad/very bad self-perception of health. Moreover, all associations are adjusted for age and gender. 
for the non-ethnic group (95\%CI: 0.60; 0.87). A significantly worse self-perceived health was also observed among those who experienced discrimination, who cannot read and write, and among the population residing in the rural area, regardless of age and gender.

Multiple regression models 1 to 4 evaluated the association with skin color adjusted for the other covariables of interest in addition to adjusting for age and gender. Models 1 and 2 suggest a stronger association with racial self-recognition than with skin color and ethnic self-recognition given that, after adjustment in the population that self-recognizes as black, the opportunity to perceive health as good is $38 \%$ lower than in the white population (95\% CI: 0.4-0.9). In contrast, the association with skin color adjusted for socioeconomic status does not change substantially (model 3), unlike what is observed when adjustments are made for the variables of discrimination, education, and place of residence (model 4). In the latter case, the association between skin color and self-perceived health approaches null and becomes less significant.

\section{Discussion}

Population aging is a global phenomenon highly related to health, and Latin America and the Caribbean have particular conditions. Specifically, according to United Nations projections, the number of people aged 60 and older is expected to increase in Latin America and the Caribbean from 77 million in 2017 to 196 million in 2050. This increase indicates that the percentage represented by older adults in the total population will increase from 12 to $25 \%$ in the period 23 . The magnitude of this older adult population growth in the region is unprecedented in history; a similar aging process occurred in Europe and North America, but gradual, taking between 50 and 100 years. In many Latin America and the Caribbean countries, this demographic change will take between 20 to 30 years 24 . In Colombia, more than half of the population in our study were in the younger group (60-69 years of age), which is consistent with the current demographic transition stage of the country, particularly with the aging processes in recent decades. Moreover, the observed higher proportion of women in the older age group could be explained by the recognized longer life expectancy of the female gender.

These demographic processes of population aging are occurring in the midst of the persistent conditions of poverty and inequality existent in Latin America and the Caribbean, in which especially the older adults live with greater precarity than the average population, combined with higher occurrence of chronic diseases, disability, and loss of autonomy typical of the age. Additionally, although all populations age, not all do so equally because this process occurs in different places and different environments, reflecting the differential distribution of the health determinants regarding inequity. Consequently, this study evaluated in particular the relationship between ethnicity/race - skin color and ethnic-racial self-recognition - and self-perceived health among older adults in Colombia.

The negative impacts of higher inequality for dark-skinned populations have been studied in the general population by Perreira \& Telles 17 through self-rated health. Our specific analysis of older adults suggests the health implications from the lifespan notion by the possible effects of cumulative exposures since childhood. However, that the differences in age ranges between the populations of PERLA and SABE can affect some of the results of the pigmentocratic effect on the perception of the subjective health condition in interaction with the other variables cannot be ignored, as observed in the analyses performed. In particular, a cohort effect can explain how one subpopulation that experienced higher mortality risk across the life course (i.e.; black populations), upon reaching older age groups will be composed of relatively more resilient members 25 .

This national population-based survey in Colombia demonstrates the consistency between the two strategies for the characterization of the ethnic-racial variable traditionally used based on selfrecognition with the strategy initially developed by the PERLA study using the color palette. This consistency suggests the benefits of using the latter classification strategy by the interviewer in large population surveys to complement the understanding of the social inequality and racial discrimination processes.

The results based on the SABE Colombia survey clearly show the social and economic gradients that occur among older adults according to skin color and ethnic and racial self-perception. Specifically, dark-skinned people that perceive themselves as black or Afro face the worst social and 
economic vulnerability, measured by their stratum and the indicator of SES conditions, given the lower education levels and the higher percentage of individuals that cannot read or write, as well as the higher percentages of the population with subsidized affiliation to the Colombian health system designed for the poor population without the capacity to pay.

These differences in the indicators mentioned reflect in part the greater rurality of older adults with darker skin color (more than one-third of them live in rural areas). They are trapped by the ruralurban socioeconomic gap and the worst living conditions of the spaces they inhabit - both urban and rural (almost 9 out of 10 dark-skinned people belong to strata SES 1 and 2). This phenomenon is a manifestation of social inequity measured by the rural-urban gap and broadened by the ethnic-racial and skin color conditions that is very expressive in the SABE sample due to the relatively stronger presence of black people in the rural area, as shown by the descriptive statistics (Table 1).

The reason for the differences between man and women ratio according to the three skin color groups variation could result from a bias effect of the SABE sample, since it does not include the ethnic-racial factor as a control variable in the sample design. This bias effect is understood by the more prevalent rurality of the black population captured in the survey, which does not mean that this represents the gender distribution of the Afro-descendant population in Colombia but rather that which the SABE sample captures. Moreover, rural-urban migration in Colombia has historically been mostly constituted of women 26,27, as observed in population censuses in the 20th and 21 st centuries and the different national household surveys by sampling.

Consistent with the previous findings of gaps according to skin color and self-recognition of ethnicity and race, the self-perception of good or very good health among older adults is less frequent in the dark-skinned population than in those with clear skin, among those who identify as black relative to those who recognize themselves as white, and among those who refer to Afro-descendant belonging relative to those without ethnicity. These findings were particularly significant for the racial selfrecognition variable, which showed that blacks were almost $40 \%$ less likely to perceive that they have good or very good health when compared with those that self-recognize as white $(\mathrm{OR}=0.61$; $95 \% \mathrm{CI}$ : 0.44; 0.84); and for the ethnic self-recognition variable in which Afros had a $28 \%$ lower probability of being perceived in good health when compared with individuals without ethnic self-recognition $(\mathrm{OR}=0.72 ; 95 \% \mathrm{CI}: 0.60 ; 0.87)$. The differences are independent of the age and gender of older adults and remain after adjustment for skin color (models 1 and 2).

In contrast, the lower frequency of perceived good health among darker-skinned people does not change significantly when adjusted for their socioeconomic status (model 3) but tends to disappear when controlled by the perception of discrimination due to reasons of race or socioeconomic condition; by conditions of inability to write/read; and by living in a rural area (model 4). We also verified a very strong association between self-reported discrimination by ethnicity/race and a worse perception of health status $(\mathrm{OR}=0.45 ; 95 \% \mathrm{CI}$ : 0.26; 0.77), suggesting the importance of social exclusion mechanisms not related to class or socioeconomic position.

The behavior of the statistical tests when compared with the color palette in models 3 and 4, in which its effect tends to disappear, can be at least partly explained by the strong rural conditions that the population of darker skin color have in the SABE sample relative to the population of lighter skin colors (Table 1). Moreover, an important association exists between the report of discrimination by ethnicity race and the worse perception of health status.

All models were adjusted for age and gender. Age shows the effect of the life course on self-rated health to the extent that the opportunity to present good/very good health decreases with aging. Older women have a $21 \%$ lower perception of good/very good health than men. Both variables were significant in all models. The results of a lower perception of good/very good health among women than men can be found in other epidemiological studies in Latin America and Spain 28,29,30,31.

This cross-sectional study demonstrates the social and economic gaps related to the ethnic-racial category in older adults in Colombia and their effects on self-perceived health. The worst self-report of general health among dark-skinned populations could influence a higher demand for health care, and more substantially, could indicate a worst health condition and a higher mortality. Therefore, the differences found by the ethnicity/race categories serve to understand the processes of exclusion that shape social health inequalities in dark-skinned populations. 


\section{Contributors}

F. Mendez participated in the study design, fieldwork supervision, data analysis and manuscript writing. F. Urrea-Giraldo contributed in the design, data analysis and article writing. D. Ortega participated in the sample design, statistical analysis and article writing.

\section{Additional informations}

ORCID: Fabian Mendez (0000-0002-5201-8822);

Fernando Urrea-Giraldo (0000-0002-4884-5972);

Delia Ortega (0000-0002-2217-3530).

\section{Acknowledgments}

We thank the Colombian Ministry or Health for funding the Colombian SABE survey. We are also grateful to Luis Gabriel Quiroz for his contribution in part of the statistical analysis.

\section{References}

1. Lasso M. Un mito republicano de armonía racial: raza y patriotismo en Colombia, 18101812. Revista de Estudios Sociales 2007; (27):32-45.

2. Urrea-Giraldo F, Viáfara C, Viveros M. Whitened miscegination to tri-etnic-multiculturalism: race and ethnicity in Colombia. In: Telles E, editor. Pigmentocracies: ethnicity, race and color in Latin America. Chapel Hill: University of North Carolina Press; 2014. p. 81-125.

3. Vinson III B. Before mestizaje: the frontiers of race and caste in colonial Mexico. Cambridge: Cambridge University Press; 2017.

4. Hering MS. Raza: variables históricas. Revista de Estudios Sociales 2007; (26):16-27.

5. Almario O. Anotaciones sobre una posible periodización de las representaciones raciales en Colombia. In: Rosero-Labbé CM, Lao-Montes A, Garavito CR, editors. Debates sobre ciudadanía y políticas raciales en las Américas $\mathrm{Ne}$ gras. Cali: Universidad del Valle; 2010. p. 35985.

6. Hering MS. Colores de piel: una revisión histórica de larga duración. In: Rosero-Labbé CM, Lao-Montes A, Garavito CR, editors. Debates sobre ciudadanía y políticas raciales en las Américas Negras. Cali: Universidad del Valle; 2010. p. 113-60.

7. De La Fuente A, Andrews G. The making of a field: afro-latin american studies. In: De la Fuente A, Andrews GR, editors. Afro-Latin American studies: an introduction. Cambridge: Cambridge University Press; 2018. p. $1-24$.

8. Solar O, Irwin A. A conceptual framework for action on the social determinants of health. Geneva: World Health Organization; 2010. (Social Determinants of Health Discussion, 2).

9. Gómez JC, Rossignolo D. La tributación sobre las altas rentas en América Latina. In: Jiménez JP, editor. Desigualdad, concentración del ingreso y tributación sobre las altas rentas en América Latina. Santiago: Comisión Económica para América Latina y el Caribe; 2015. p. 49-113.

10. Telles E. Pigmentocracies: ethnicity, race and color in Latin America. Chapel Hill: University of North Carolina Press; 2014.

11. Andrews G. Whiteness and its discontents. In: Alberto P, Elena E, editors. Rethinking race in modern Argentina. Cambridge: Cambridge University Press; 2016. p. 318-26.

12. Ferreira R, Seijas T. Inequality: race, class, gender. In: De la Fuente A, Andrews GR, editors. Afro-Latin American studies: an introduction. Cambridge: Cambridge University Press; 2018. p. 52-91.

13. Telles E, Bailey S. Understanding Latin American beliefs about racial inequality. AJS 2013; 118:1559-95.

14. Telles E, Flores R. More than just color: whiteness nation and status in Latin America. Hisp Am Hist Rev 2013; 93:411-49. 
15. Telles E, Flores R, Urrea F. Pigmentocracies: educational inequality, skin color and census ethnoracial identification in eight Latin American countries. Res Soc Stratif Mobil 2015; 40:39-58.

16. Wong R, Peláez M, Palloni A. Autoinforme de salud general en adultos mayores de América Latina y el Caribe: su utilidad como indicador. Rev Panam Salud Pública 2005; 17:323-32.

17. Perreira K, Telles E. The color of health: skin color, ethnoracial classification, and discrimination in the health of Latin Americans. Soc Sci Med 2014; 116:241-50.

18. Ministerio de Salud y Protección Social. Envejecimiento demográfico. Colombia 1951-2020. Dinámica demográfica y estructuras poblacionales. Bogotá: Ministerio de Salud y Protección Social; 2013.

19. Krieger N. Epidemiology and the people's health: theory and context. New York: Oxford University Press; 2011.

20. Gómez F, Corchuelo J, Curcio CL, Calzada MT, Mendez F. SABE Colombia: survey on Health, Well-Being, and Aging in Colombia - study design and protocol. Curr Gerontol Geriatr Res 2016; 2016:7910205.

21. Suliman E, Wagstaff A, Amouzou A. Socioeconomic differences in heatlh, nutrition, and population within developing countries. Washington DC: World Bank; 2007.

22. Telles E, Steele L. Pigmentocracia en las Américas: ¿cómo se relaciona el logro educativo con el color de piel? Nashville: Vanderbilt University; 2012. (Perspectivas Desde el Barómetro de las Américas, 73)

23. Population Division, Department of Economic and Social Affairs, United Nations. World population prospects: the 2017 revision. Key findings and advance tables. New York: United Nations; 2017. (Working Paper ESA/P/ $\mathrm{WP} / 248)$.
24. National Academies of Sciences, Engineering, and Medicine. Strengthening the scientific foundation for policymaking to meet the challenges of aging in Latin America and the $\mathrm{Ca}$ ribbean: summary of a workshop. Washington DC: The National Academies Press; 2015.

25. Masters RK. Uncrossing the U.S. black-white mortality crossover: the role of cohort forces in life course mortality risk. Demography 2012; 49:773-96.

26. Flórez CE. Las transformaciones sociodemográficas durante el siglo XX. Bogotá: Editorial Banco de La República; 2000.

27. Arias MA, Caro A, Farah MA, Henao A, Ibañez AM, Muñoz JS, et al. El nuevo perfil de las mujeres rurales en Colombia. Lima: Instituto de Estudios Peruanos; 2013.

28. López E, Findling L, Abramzón M. Desigualdades en salud: ¿Es diferente la percepción de morbilidad de varones y mujeres? Salud Colect 2006; 2:61-74.

29. Abascal I, Ramírez MF. Diferencias relacionadas con la salud de mujeres y hombres adultos mayores. Rev Cuba Med Gen Integr 2013; 29:281-96.

30. Peláez E, Acosta LD, Carrizo ED. Factores asociados a la autopercepción de salud en adultos mayores. Rev Cuba Salud Pública 2015; 41:638-48.

31. Parra-Rizo MA. Diferencias de género en la percepción de salud en personas mayores de 60 años físicamente activas. Revista Española de Comunicación en Salud 2017; 8:219-27. 


\section{Resumen}

Este estudio está basado en la encuesta Colombia $S A B E$ (Salud, Bienestar, y Estudio de Envejecimiento), que incluyó a 23.694 personas con 60 años o más en áreas urbanas y rurales del país. El análisis se dirige a la autopercepción del estado de salud que tienen los adultos, como variable dependiente y sus correlaciones con el autorreconocimiento étnico/racial, así como el color de piel adscrito por parte del entrevistador -como rasgo fenotípico-, usando una técnica validada mediante una gama de colores. Las inequidades sociales se determinaron basándose en la caracterización del estatus socioeconómico, residencia urbana o rural, alfabetización, y el promedio de años de educación completados. A través del análisis mencionado anteriormente, este estudio aunó factores socioeconómicos con el autorreconocimiento étnico-racial $y$ el color de piel, como factor de discriminación. Se desarrollaron tests estadísticos descriptivos $y$ cuatro modelos logísticos ajustados, que fueron desarrollados controlando sexo y edad de los participantes. Los resultados revelan que los adultos en los hogares con mejores condiciones socioeconómicas tuvieron una mejor autopercepción de salud. Respecto al autorreconocimiento étnico-racial, afrodescendiente, negro, y adultos mulatos, tienen una percepción menos buena de salud, en comparación con los adultos blancos-mestizos, además de enfrentar peores condiciones socioeconómicas. En resumen, color de piel, categorías étnicas, así como las raciales de autorreconocimiento, junto con las clásicas variables socioeconómicas, son relevantes para el autopercepción del estatus de salud de los adultos de edad avanzada, como parte de los procesos de exclusión y discriminación que tienen consecuencias, debido a las inequidades de salud.

Grupos Étnicos; Racismo; Inequidad Social; Salud del Adulto

\section{Resumo}

$O$ artigo teve como base a pesquisa SABE (Saúde, Bem-Estar e Envelhecimento) da Colômbia, que incluiu 23.694 indivíduos com 60 anos ou mais nas áreas urbana e rural do país. A análise trata $o$ autorrelato da saúde como variável dependente e as relações com o autorrelato étnico-racial e a cor da pele relatada pelo entrevistador enquanto traço fenotípico, através de uma técnica validada usando uma paleta de cores. As desigualdades sociais foram determinadas com base na caracterização da condição socioeconômica, residência urbana ou rural, alfabetização e anos de estudo. Através dessa análise, o estudo construiu fatores socioeconômicos com autorrelato étnico racial e cor da pele como fator de discriminação. Foram desenvolvidos testes estatísticos descritivos e quatro modelos logísticos, ajustados por sexo e idade. Os achados mostram que adultos com melhores condições socioeconômicas apresentam melhor autorrelato da saúde. Com relação ao autorrelato étnico-racial, os adultos afrodescendentes, negros e mulatos apresentam, em média, pior autorrelato da saúde quando comparados aos adultos brancos e mestiços, além de piores condições socioeconômicas. Em resumo, as categorias de cor e de autorrelato étnico e racial, junto com variáveis socioeconômicas tradicionais, são relevantes para compreender o autorrelato da saúde dos idosos como parte dos processos de exclusão e discriminação que têm consequências para as desigualdades em saúde.

Grupos Étnicos; Racismo; Iniquidade Social; Saúde do Adulto
Submitted on $02 / \mathrm{Jul} / 2019$

Final version resubmitted on 04/Oct/2019

Approved on 12/Mar/2020 